\title{
Clayey soils from Boulgou (North Cameroon): geotechnical, mineralogical, chemical characteristics and properties of their fired products
}

\author{
A. Nzeukou Nzeugang ${ }^{1}$ (D) D. Tsozué ${ }^{1}$ - B. Kagonbé Pagna ${ }^{1,2} \cdot$ A. Balo Madi ${ }^{2} \cdot$ A. Fankam Deumeni ${ }^{3} \cdot$ S. Ngos III ${ }^{1}$ \\ C. Nkoumbou ${ }^{3} \cdot$ N. Fagel $^{4}$
}

Received: 21 September 2020 / Accepted: 29 March 2021 / Published online: 13 April 2021

(c) The Author(s) $2021 \quad$ OPEN

\begin{abstract}
In this study, clayey soils are characterized as backfill and potential fusible raw materials for engineering. Geotechnical tests (particle size distribution, Atterberg limits, densities) and chemico-mineralogical analyses (X-ray fluorescence, $\mathrm{X}$-ray diffraction and Fourier transform infrared) were carried out on samples collected from field in the locality of Boulgou (North Cameroon) followed by the determination of mechanical properties of fired bricks $\left(850-1200^{\circ} \mathrm{C}\right)$. The excavations carried out have revealed a thick layer of clayey soils ( 2 to $2.5 \mathrm{~m})$ over a sandy layer. This clay formation presents some stratifications with limited influence variation in terms of mineralogy. Mean grain size distribution is dominated by sand $(62-80 \%)$, clay $(12-25 \%)$ and silt (6-9\%). It corresponds to silty-clayey soils regarding their methylene blue values (3.3-5.6), with low plastic (13-22\%) to high plastic (33\%) characteristics. They are classified by USCS as clayey sand/ silty clay, while one sample is a poorly graded sand (SP). Clay minerals observed are kaolinite (6-12\%), montmorillonite $(2-6 \%)$ and illite (8-10\%). Those parameters associated with their fine nature and high compressibility make them suitable engineering applications for backfill material and barriers. From chemical analyses, relatively high contents in alkali and alkaline earth elements ( 4 to $6 \%$ ) to be used as potential fusible raw materials for fired bricks or gres ceramics were revealed. Bricks characteristics are varied: linear shrinkage $(0.3$ to $9 \%)$, bulk density $\left(1.8\right.$ to $\left.2.3 \mathrm{~g} / \mathrm{cm}^{3}\right)$, water absorption $(19.7$ to $1.3 \%)$ and flexural strength $(0.3$ to $17.4 \mathrm{MPa})$. Overall, the requirement for fired brick $(<20 \%)$ is met up by the water absorption values. As from $1050^{\circ} \mathrm{C}$, these soils are made suitable for brick-making with good characteristics (metallic sound, good cohesion and flexural strength).
\end{abstract}

Keywords Clayey soil characteristics · Engineering applications · Fired products · Cameroon

\section{Introduction}

The use of clayey soils as support materials, backfill or raw material by engineers cannot be done without prior characterization. The behaviors of clays are related to their mineralogy and chemical composition, associated with certain geotechnical characteristics (particle size, plasticity, etc.).
In engineering applications, much caution is implied in the utilization of the diversified nature of soils, as problematic soils may be enhanced by several additives or admixtures $[1,2]$. As a result, the interest in a given raw material can positively impact the economic development of a region or a country. Satisfying the demand for construction materials implies developing the supply by multiplying

A. Nzeukou Nzeugang, nzeuk@yahoo.fr | ${ }^{1}$ Department of Earth Sciences, University of Maroua, P.O. Box 814, Maroua, Cameroon. ${ }^{2}$ Local Materials Promotion Authority (MIPROMALO), P.O. Box 2396, Yaoundé, Cameroun. ${ }^{3}$ Department of Earth Sciences, University of Yaoundé 1, P.O. Box 812, Yaoundé, Cameroon. ${ }^{4}$ Laboratory of Clays, Geochemistry and Sedimentary Environments (AGEs), Department of Geology, University of Liege, 4000 Liège, Belgium. 
production units. For example, the transformation of clay into building materials (bricks, tiles, etc.) contributes to the development of the local economy (creation of local jobs that cannot be relocated). Many researchers are focusing their works on clayey soils in engineering applications such as geopolymers for road and building materials [3], ceramic application for fired bricks and porcelains [4-7] and materials for backfill and core of earth fill dams [2, 8-11]. In North Cameroon, clayey soils at Boulgou are extracted by the local population for pottery, plastering walls of houses and the production of construction materials (adobes and fired bricks using clamp kilns). These soils are extensively present in the locality, easily noticed by the cracks left beside when they are dried out. The rising interest of local population in these raw materials for the applications mentioned above shows up a potential for a large-scale exploitation which requires the appraisal of their engineering properties. This study deals with the chemico-mineralogical and geotechnical characteristics of materials issued from the alteration of the geological massif of Boulgou (Northern Cameroon) for appropriated firing products and other potential valorizations in engineering application.

\section{Geographical and geological setting}

The site under study is located in Boulgou, one of the 178 villages found in Benue division, North Region of Cameroon. The village is at the foot of the Tinguelin massif, at an average altitude of around $230 \mathrm{~m}$. The exploratory zone is limited by latitudes N09 $26^{\prime} 24^{\prime \prime}$ and N09 $24^{\prime} 04^{\prime \prime}$ and longitudes E13 $3^{\circ} 27^{\prime} 24^{\prime \prime}$ and E13 $3^{\circ} 29^{\prime} 45^{\prime \prime}$, with a total area of $19.18 \mathrm{~km}^{2}$ (Fig. 1). A typical Sudanian climate reigns in the Benue with two contrasted seasons: a rainy season from May to October and a dry season from November to April. The mean annual rainfall is generally less than $1 \mathrm{~m}$, with however a variation from one year to another and also one month to another [12].

The study area is on a very gentle slope within the alignment of the Tinguelin massif in the west and north, taking the form of a semicircle. This area corresponds to a peneplain with an altitude around $200 \mathrm{~m}$ (Fig. 1). The Tinguelin massif is made of tabular "sandstone" hills known as the Hosséré (Hosséré Sonayo, Hosséré Boulgou, Hosséré Banay), with varying elevation (from 540 to $660 \mathrm{~m}$ ). According to [12], numerous outcrops appear in the study area and form a massif made up of a set of sandstone hills which overlay in discordance on a tectonized microgranite (faults with sinistral steps visible on the offset of the quartzo-feldspathic veins). The lithological section of the Hosséré Tinguelin is made up of conglomerate, microconglomerat, coarse sandstone, fine sandstone, siltite and clay
[12]. The mineralogy of microgranite is made up of quartz, potassic feldspar, albite, mica and amphibole. Sandstones are the most observed sedimentary rocks and, in some places, conglomeratic over centimetric layers, with no feldspars in their mineralogical composition. This mineralogy is mainly consisted of quartz, micas and heavy elements (zircon, rutile) [12].

\section{Materials and method}

\subsection{Prospection and sampling techniques}

Five (05) wells were dug during the field trips: three newly excavated (P1, P2 and P3) and two refreshed and deepened (P4 and P5) (Fig. 2, Table 1). Wells were dug according to the morphology of the study area and the positions where villagers collected their clayey soils for pottery activities by craftsmen. A sample (SPmG) was collected at the Gobbri hill (269 m altitude, Fig. 1), and a high content of coarse grains was shown through its observation as for the other sampling points. However, it is not of a particular interest to the local population. After the description of soil profiles, samples were collected manually with a shovel at the center from the various layers crossed (Table 1). Due to the hardness of the soil at that particular season of the year (dry season), a hand auger was used as from the deepest layers which is less hard than the superficial ones, in order to deepen the hole. Samples were collected according to the color, texture and the presence of nodules following each facies. Gray color is dominant, and after reconstitution, P4 shows sandy materials essentially. Samples collected undergone different analyses in the laboratory, and samples from different layers were first characterized in terms of granulometry, plasticity and mineralogy. After the first characterization, no particular difference between layer 1 and 2 was observed in all wells dug. The slight changes in composition of the soil are just in terms of their visual aspect (texture, presence or absence of roots). However, no major difference between clayey and sandy clayey layers was shown from mineralogical results. In P1 profile for example constituted of layers P1C1/P1C2, P1C3 and $\mathrm{P} 1 \mathrm{C} 4$, it was observed that all those layers are overall homogenous; the difference from one layer to another is at the level of their apparent concentration in millimetric or centimetric nodules. With regard to the thickness of the reserve clayey materials ( 2 to $3.5 \mathrm{~m}$ ) and the interest focused on their global exploitation, a composite sample was obtained from an equitable gramme of clayey and sandy clayey layers in each well dug. Each reconstructed sample (P1 to P5) was undergone geotechnical (density, porosity, etc.), mineralogical and chemical analyses. 
Fig. 1 a Sampling map superposed on the geomorphological map of Garoua 07253-1d-NC -33-VIII-1d 3 at $1 / 50000$ scale; $\mathbf{b}$ Geological map of the study area
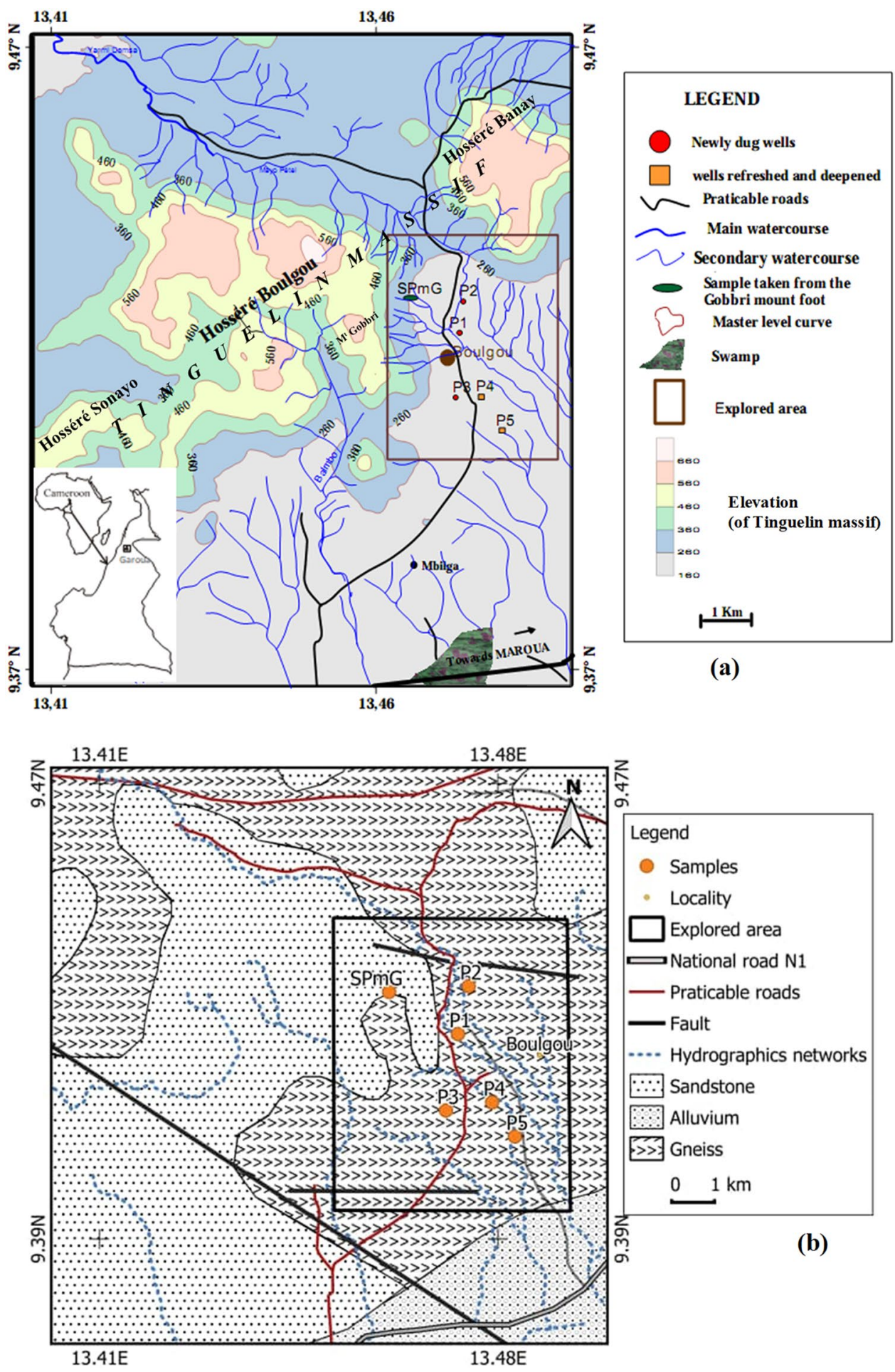

\subsection{Determination of geotechnical properties}

Particle size distribution, Atterberg limits, test of methylene blue and density were considered as geotechnical characteristics of the studied clayey soils. The particle size distribution was obtained after sieving of fraction $\geq 80 \mu \mathrm{m}$ and sedimentation for the fraction $<80 \mu \mathrm{m}$ (D-422 ASTM standards). The Atterberg limits (liquid limit-LL, plastic limit-PL and plasticity index-PI) were resulted from the Casagrande method (D-4318 ASTM standards). The capacity of clay to absorb cations from a solution is determined by the test of methylene blue (VBS), and it is a parameter which helped to characterize the clayey density (cleanliness) of a soil. It was determined according to the formula 

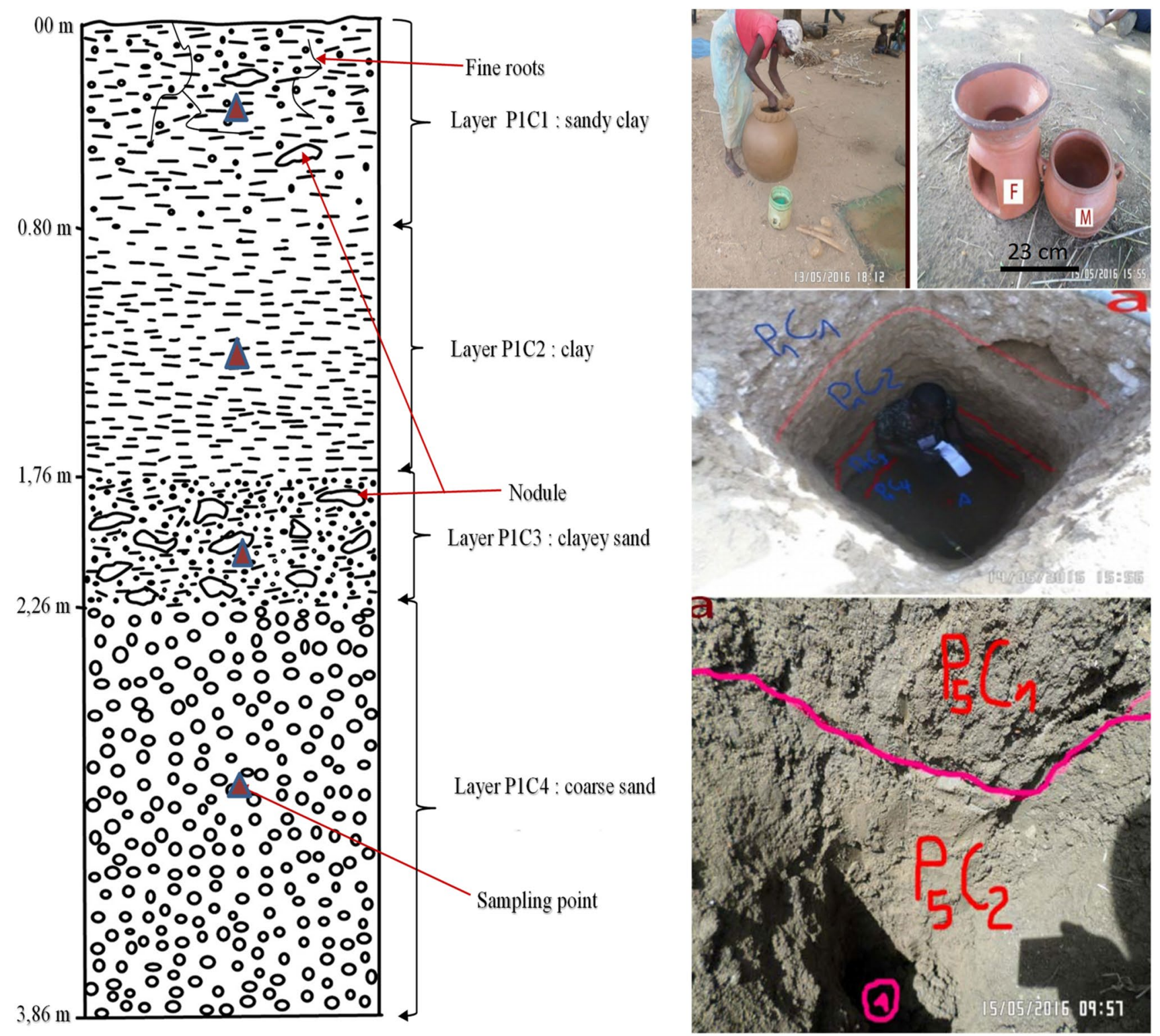

Fig. 2 Vertical section across the alluvial deposits in Boulgou valley. (Illustration of P1 profil constituted of layers P1C1, P1C2, P1C3 and P1C4. All those layers are homogenous on the overall; the difference from one layer to another is at the level of their apparent

of Skemptom (1973) in [1] (Table 2). The water content $(\omega)$ of each sample collected in the field was obtained by double weighing, the first for the raw sample $(W)$ and the second after been dried in the oven (at $105^{\circ} \mathrm{C}$ ) to a constant mass $(W d)$.

To better interpret particle size distribution and Atterberg limits results, and characterize the studied clayey soils for the geotechnical design, appropriate coefficients (heterometry- $C_{h}$, uniformity- $C_{u}$, curvature- $C_{C}$ ) and some parameters (Table 2) are determined from [13]). For $C_{h}$, the more the parameters $d 85$ and $d 15$ differ, the more the concentration in millimetric or centimetric nodules. Ceramic wood stove $(\mathrm{F})$ and pottery $(\mathrm{M})$ produced by the local population using clayey materials from Boulgou

studied soil is heterogranular. The spreading of the curve is reflected by $C_{U}$ and $C_{C}$ is relative to the shape of the curve. The activity coefficient of clay is defined as the ratio $\mathrm{PI}$ to the percentage of grain $<2 \mu \mathrm{m}$ in effective diameter. The bulk density (dry volumetric weight $\left(\gamma_{\mathrm{d}}\right)$ ) is the weight of a given volume of soil, including the network of pore spaces, while the real soil density (solid volumetric grain weight $\left(\gamma_{s}\right)$ ) excludes the pore spaces. The bulk density and the real density are obtained, respectively, by a succession of weighing and a pycnometer, following the procedure defined by Robitaille and Tremblay [13]. By combining the 
Table 1 Macroscopic description of profiles

\begin{tabular}{|c|c|c|c|}
\hline Borehole & \multicolumn{2}{|c|}{ Description } & Localization \\
\hline \multicolumn{4}{|l|}{ P1 } \\
\hline \multicolumn{4}{|l|}{$3.86 \mathrm{~m}$} \\
\hline $\mathrm{P} 1 \mathrm{C} 1$ & \multicolumn{2}{|c|}{$\begin{array}{l}0.80 \mathrm{~m} \text { thick, sandy clayey texture, gray light color, compact, presence of centimetric nodules (until } \\
10 \mathrm{~cm} \text { ) and few roots }\end{array}$} & $\begin{array}{l}{\mathrm{N} 09^{\circ} 25.615^{\prime}}^{\mathrm{E}^{\prime} 13^{\circ} 28.423^{\prime}}\end{array}$ \\
\hline $\mathrm{P} 1 \mathrm{C} 2$ & \multicolumn{2}{|c|}{$0.96 \mathrm{~m}$ thick, clayey texture, gray color, compact, progressive limit with upper layer } & Altitude: $241 \mathrm{~m}$ \\
\hline P1C3 & \multicolumn{2}{|c|}{$\begin{array}{l}0.50 \mathrm{~m} \text { thick, clayey sandy texture, gray light color, compact, presence of nodules more than P1C1, net } \\
\text { limit with upper layer }\end{array}$} & \\
\hline P1C4 & \multicolumn{2}{|c|}{$1.6 \mathrm{~m}$ thick, sand, net limit with upper layer } & \\
\hline \multicolumn{4}{|l|}{ P2 } \\
\hline \multicolumn{4}{|l|}{$2.5 \mathrm{~m}$} \\
\hline $\mathrm{P} 2 \mathrm{C} 1$ & \multicolumn{2}{|c|}{$0.50 \mathrm{~m}$ thick, sandy clayey texture, gray light color, presence of centimetric nodules, few roots } & N09 $25.936^{\prime}$ \\
\hline $\mathrm{P} 2 \mathrm{C} 2$ & \multicolumn{2}{|c|}{$0.67 \mathrm{~m}$ thick, clayey texture, gray color, compact, progressive limit with upper layer } & $\mathrm{E}^{0} 13^{\circ} 28.050^{\prime}$ \\
\hline $\mathrm{P} 2 \mathrm{C} 3$ & \multicolumn{2}{|c|}{$0.15 \mathrm{~m}$ thick, millimetric nodules concentration, net limit } & Altitude: $259 \mathrm{~m}$ \\
\hline $\mathrm{P} 2 \mathrm{C} 4$ & \multicolumn{2}{|c|}{$1.08 \mathrm{~m}$ thick, clayey texture, compact } & \\
\hline \\
\hline \multicolumn{4}{|l|}{$2 \mathbf{m}$} \\
\hline $\mathrm{P} 3 \mathrm{C} 1$ & \multicolumn{2}{|c|}{$0.30 \mathrm{~m}$ thick, sandy clayey texture, gray color, few roots } & N09 $24.899^{\prime}$ \\
\hline $\mathrm{P} 3 \mathrm{C} 2$ & \multicolumn{2}{|c|}{$1.70 \mathrm{~m}$ thick, clayey texture, gray yellowish color, compact, progressive limit with upper layer } & $\begin{array}{l}\text { E013 } 28.603^{\prime} \\
\text { Altitude: } 229 \mathrm{~m}\end{array}$ \\
\hline \multicolumn{4}{|l|}{ P4 } \\
\hline \multicolumn{4}{|l|}{$2 \mathbf{m}$} \\
\hline $\mathrm{P} 4 \mathrm{C} 1$ & \multicolumn{2}{|c|}{$0.45 \mathrm{~m}$ thick, fine sand, dark color, more roots than other holes } & N09 $24.888^{\prime}$ \\
\hline $\mathrm{P} 4 \mathrm{C2}$ & \multicolumn{2}{|c|}{$1.55 \mathrm{~m}$ thick, fine sand as $\mathrm{P} 4 \mathrm{C} 1$, gray yellowish color, net limit with upper layer } & $\begin{array}{l}\text { E013 } 28.766^{\prime} \\
\text { Altitude: } 219 \mathrm{~m}\end{array}$ \\
\hline \multicolumn{4}{|l|}{$\begin{array}{l}\text { P5 } \\
2.5 \mathrm{~m}\end{array}$} \\
\hline $\mathrm{P} 5 \mathrm{C} 1$ & \multicolumn{2}{|c|}{$0.65 \mathrm{~m}$ thick, sandy clayey texture, dark color } & N09 $24.525^{\prime}$ \\
\hline $\mathrm{P} 5 \mathrm{C} 2$ & \multicolumn{2}{|c|}{$1.95 \mathrm{~m}$ thick, clayey texture, gray light color, progressive limit with upper layer } & $\begin{array}{l}\text { E013 } 28.992^{\prime} \\
\text { Altitude: } 210 \mathrm{~m}\end{array}$ \\
\hline $\begin{array}{l}\text { Table } 2 \mathrm{G} \\
\text { parameter }\end{array}$ & & $\begin{array}{l}\text { (1)VBS }=\frac{\text { volume of methylene blue used }}{\text { mass of dry sample }} * 100 \quad \text { (2) } A=\frac{\text { Plasticity }}{\% \text { of clay }<2 \mu \mathrm{m}} \\
\begin{array}{lll}\text { (4) } \omega=\frac{W-W_{\mathrm{d}}}{W_{\mathrm{d}}}(5) \gamma_{\mathrm{d}}=\frac{W_{\mathrm{d}}}{V}(6) \gamma_{\mathrm{S}}=\frac{W_{\mathrm{s}}}{V_{\mathrm{s}}}(7) n=1-\frac{\gamma_{\mathrm{d}}}{\gamma_{\mathrm{s}}}(8) e=\frac{n}{1-n} \text { (9) } c=1-n(10) S_{\mathrm{h}}=\frac{d_{85}}{d_{15}} C \cdot \gamma_{\mathrm{s}} \\
\text { (2) from Skemptom (1973) in [1]; (3 to } 10 \text { in [13]) }\end{array}\end{array}$ & $=\frac{d_{60}}{d_{20}} C_{C}=\frac{d_{30}^{2}}{d_{30} \cdot d_{10}}$ \\
\hline
\end{tabular}

two densities, we have derived by applying soil mechanics formulas: the porosity $(n)$, void ratio $(e)$, compacity $(C)$ and degree of saturation (Sr).

\subsection{Mineralogical and chemical analyses}

X-ray diffraction equipment was used to obtain total and clay fractions on both disoriented powders and oriented aggregates (measurements in $2 \theta$ range from $2^{\circ}$ to $45^{\circ}$ with a scan step size of $0.02^{\circ}$ and time per step of 2 s). A Bruker Advance D8 diffractometer (copper Ka1 radiations, $\lambda=1.5418 \AA, V=40 \mathrm{kV}, I=30 \mathrm{~mA}$ ) was used in study, at the Laboratory of Clays, (Geochemistry and sedimentary Environment, University of Liège, Belgium), according to the methodology of Moore Duane and
Reynolds Robert [14]. Identification through air-drying $(24 \mathrm{~h})$, glycolation $(22 \mathrm{~h})$ and heating $\left(500^{\circ} \mathrm{C}\right.$ for $4 \mathrm{~h}$ ) was done with further tests. Mineral phases present in the studied sample were better identified with Eva software. Estimations (qualitative and semi-quantitative) according to Biscaye (1965) in [15] ( $\pm 5-10 \%)$ were referred to peak intensity measurements of X-ray patterns [15]. For Fourier transform infrared spectra, a Nicolet NEXUS spectrometer was used following the protocol standard ( $2 \mathrm{mg}$ of sample mixed with $180 \mathrm{mg}$ of $\mathrm{KBr}$ ). The chemical results were obtained using an X-ray fluorescence spectroscopy (Bruker S8 Tiger $4 \mathrm{~kW}$ ) at the Laboratory of "Pétrologie, géochimie endogènes et pétrophysique (PGEP)" University of Liège, Belgium. 


\subsection{Firing of specimens and properties}

To study the evolution of firing properties, the clay samples were first dried, crushed in a mortar $(\varnothing<1 \mathrm{~mm})$ before being mixed with water (14 to $15 \%$ ) by hand homogenization. Water was added in each powder progressively until a percentage facilitating the pressing process (on $100 \mathrm{~g}$ of powder the corresponding water content is $14 \mathrm{~g}$ ). The test specimens $(80 \times 40 \times 18) \mathrm{mm}$ were made using a $10 \mathrm{kN}$ hydraulic press with a compaction pressure of $3.1 \mathrm{MPa}$, then dried at ambient atmosphere for $72 \mathrm{~h}$ and then oven-dried $\left(105^{\circ} \mathrm{C}\right)$ for $24 \mathrm{~h}$. The dried specimens were fired between 850 and $1200^{\circ} \mathrm{C}$ for $5 \mathrm{~h}$ at a heating rate of $5{ }^{\circ} \mathrm{C}$ per minute in a Multimate furnace. That heating speed corresponds to slow-firing cycle, which is generally used for substance which decompose and for red ceramic manufacture [16]. The appearance of a larger amount of newly phases during sintering is favored by the use of a slow-firing cycle and the properties (density, flexural strength, etc.) of the final products $[7,16]$ are enhanced. Properties as color, cohesion, sound absorption, linear shrinkage, water absorption, density and flexural strength were determined. A metal rod was used by knocking on the fired specimens in order to qualify the sonority, and the Munsell Soil Color Chart to determine the color. We have obtained the bulk density after having divided the weigh mass of fired specimen to the measured volume. The firing shrinkage is the ratio: $100\left(L_{m}-L_{f}\right) / L_{m}$ where $L_{m}$ is the length of the mold and $L_{f}$ is the length of the fired specimen. The water absorption and flexural strength were determined using ASTM norm C373-72 and C67477 , respectively. The average of each result was derived from 03 samples tested.

\section{Results and discussion}

\subsection{Geotechnical properties}

A certain granular homogeneity was shown by the granulometric data of the studied clayey soils except for sample P4 which is exclusively sandy (100\% of fraction $>20 \mu \mathrm{m})$ (Table 3). Regarding the values of some particle size distribution coefficients $\left(C_{\mathrm{h}}>200, C_{\mathrm{u}}>2\right.$ and $\left.C_{\mathrm{c}}>3\right)$, the studied clayey soils were led to very spread materials, which characterize a particle size distribution where all the grain sizes
Table 3 Geotechnical properties of Boulgou clayey soils

\begin{tabular}{|c|c|c|c|c|c|c|}
\hline & $\mathrm{P} 1$ & $\mathrm{P} 2$ & P3 & P4 & P5 & SPmG \\
\hline Clay $(<2 \mu \mathrm{m})(\%)$ & 18 & 22 & 12 & 0 & 25 & 24 \\
\hline Silt: - $(0.02>\phi>0.002 \mathrm{~mm})(\%)$ & 7 & 9 & 8 & 0 & 10 & 6 \\
\hline Sand: - $(2>\phi>0.02 \mathrm{~mm})(\%)$ & 61 & 63 & 79 & 80 & 64 & 62 \\
\hline Gravel-(> $2 \mathrm{~mm})(\%)$ & 14 & 6 & 1 & 20 & 1 & 8 \\
\hline Fine fraction $(<80 \mu \mathrm{m})$ & 35 & 45 & 27 & - & 53 & 42 \\
\hline Fraction $(>20 \mu \mathrm{m})$ & 74 & 69 & 80 & 100 & 65 & 70 \\
\hline Liquid limit (LL) (\%) & 47.1 & 47.1 & 35.1 & - & 34.2 & 56.5 \\
\hline Plastic limit (PL) (\%) & 25.8 & 24.5 & 22.7 & - & 14.3 & 23.5 \\
\hline Plastic index (PI) (\%) & 21.3 & 22.6 & 12.4 & - & 19.8 & 33.1 \\
\hline Water content $(w)(\%)$ & 6.3 & 5.0 & 7.8 & - & 11.7 & 5.9 \\
\hline Consistency index (= (LL-w)/PI) & 1.9 & 1.8 & 2.2 & - & 1.1 & 1.5 \\
\hline Activity value & 1.18 & 1.02 & 1.03 & - & 0.79 & 1.37 \\
\hline Methylene Blue (g/100 g) & 5.53 & 4.33 & 3.33 & - & 5.67 & 4.67 \\
\hline Coefficient of heterometry (Ch) & $>200$ & $>200$ & 100 & $>200$ & $>200$ & $>200$ \\
\hline Coefficient of uniformity $(\mathrm{Cu})$ & 80 & 154 & 6 & $>2$ & $>2$ & $>2$ \\
\hline Coefficient of curvature (Cc) & $>3$ & $>3$ & $>3$ & $>3$ & $>3$ & $>3$ \\
\hline Bulk density $\left(\gamma_{d}\right)\left(\mathrm{g} / \mathrm{cm}^{3}\right)$ & 2.73 & 2.07 & 2.01 & - & 1.71 & 1.7 \\
\hline Real density $\left(\gamma_{\mathrm{s}}\right)\left(\mathrm{g} / \mathrm{cm}^{3}\right)$ & 2.94 & 3.13 & 2.78 & - & 3.13 & 1.9 \\
\hline Porosity $(n)(\%)$ & 7.14 & 33.9 & 27.7 & - & 45.3 & 8.8 \\
\hline Void ratio $(e)$ & 0.07 & 0.25 & 0.21 & - & 0.31 & 0.08 \\
\hline Compacity (c) (\%) & 92.9 & 61.1 & 72.3 & - & 54.6 & 91.1 \\
\hline Degree of saturation (Sr) (\%) & 2.76 & 0.62 & 0.99 & - & 1.17 & 1.39 \\
\hline \multirow[t]{2}{*}{ USCS' classification } & $\mathrm{SC}$ & SC & SC & $\mathrm{SP}$ & SC & SC \\
\hline & Clayey sand & & Silty clay & $\begin{array}{l}\text { Poorly } \\
\text { graded } \\
\text { sand }\end{array}$ & Clayey sand & \\
\hline
\end{tabular}


are not represented, thus translating a multiple genesis process [17]. The proportion of the fine fraction $(<80 \mu \mathrm{m})$ $(27-53 \%)$ and the Atterberg limits values were allowed their classification according the Unified Soils Classification System (USCS). P1, P2, P5 and SPmG can be classified as clayey sand (SC) while sample P3 is silty clay (SC) and P4 a poorly graded sand (SP) (Table 3 ). In the Casagrande chart (Fig. 3a), samples studied can be classified as low plasticity clay (CL) for P1, P2, P3 and P5 while sample SPmG is a high plasticity clay $(\mathrm{CH})$. The positioning of the various samples in the porosity and permeability diagrams (Fig. 3b) [18] is classified as low permeability with highporosity (P3) and low-porosity materials for other samples, which therefore have high cohesion and are easily extrudable. The P3 well is rich in very porous and highly permeable materials, which sounds very logical in view of their particle size distribution (silty clay). Based on these results and according to $[10,19]$ for their use as backfill materials, the poorly graded materials (P4) may require saturation with downward drainage and compaction with greater compaction effort to achieve sufficiently high densities. P1 to P5 classified as low plasticity clay $(\mathrm{CL})$ were relatively impervious and can be compacted fairly easily with heavy compaction equipment to provide a good stable backfill $[10,19]$. SPmG with their high plasticity $(\mathrm{CH})$ may be considered as marginal backfill materials, and their usage should be based on economic considerations, including the cost to obtain suitable backfill materials. Otherwise, using $\mathrm{CH}$ soils should be avoided in confined areas due to the fact that a high degree of compaction is needed to minimize backfill settlement or to provide a high compression modulus $[10,19,20]$. In the manufacturing process of fine ceramics, plasticity is one of the properties sought because it facilitates the shaping of the greenwares and ensures their cohesion. In Bain and Highley diagram's [21], approximate clays of low plasticity (P3) and high plasticity (P1, P2, P5 and SPmG) were studied in clayey soils. Samples are extrudable except SPmG probably due to its high plasticity. $\mathrm{P} 3$ and $\mathrm{P} 5$ are good for brick-making with optimal extrusion process while others samples are good for pottery activities (Fig. 3c). Following their plasticity, it is known that clayey soils with plasticity index $(\mathrm{PI})<10 \%$ may bring cracks during the extrusion process and are not appropriate for building-related ceramic production, due to the possible variation in the amount of extrusion water $[22,23]$. Clayey studied soils have a PI higher than $10 \%$, meaning that they might be used in their raw state for structural ceramics products obtained by extrusion [23].

The activity coefficients were all beyond 0.75 , revealing that the clays are active and belong to the smectitic clay group according to Skemptom's classification [1]. These facts provide an indication of the potential expansion of clays studied. The methylene blue values are varied between 3.33 and 5.53, which corroborates the clay content (12-25\%), confirming that clayey soils studied are rich in 2:1 clay mineral explaining the swelling behavior observed on the field.

The bulk density values vary between 1.71 (P5) and 2.73 (P1) and the real density is ranged from 1.92 (SPmG) to 3.13 (P2 and P5). These values are greater than 1.5, meaning that soils studied are very heavy with coarse fragments in texture. The clayey soils from Boulgou exhibit a porosity variation ranging from 7.14 to $45.37 \%$, a very weak saturation in water $(0.62 \%<\mathrm{Sr}<2.76 \%)$, with relatively low void ratio $(0.07<e<0.31)$, indicating the high compactness $(54.63<C<92.86)$ observed in the field during digging. The origin of these clayey soils may be related to the bisiallitization weathering mechanism favored by hydrological and morphoclimatic conditions in the northen area of Cameroon. All these factors lead to the concentration of bases $\left(\mathrm{K}_{2} \mathrm{O}, \mathrm{Na}_{2} \mathrm{O}, \mathrm{CaO}\right)$ and silica $\left(\mathrm{SiO}_{2}\right)$ creates favorable conditions for the genesis of montmorillonite mineral (smectite) which have significant swelling potential due to large seasonal variations in moisture and rainfall $[4,9$, 24]. In that area, this behavior can damage some engineering structures such as single-family residential buildings. Referring to the USCS classification, the studied clayey soils were judged unsuitable for civil engineering works. Also, problems may occur when clayey materials are used with expansive characteristics as backfill materials according to $[10,19]$. Those problems (rise of groundwater, seepage, leakage, or elimination of surface evaporation) may increase or decrease the water content of compacted soil and lead to the tendency to expand or shrink. A lime solution can be mixed with some expansive clays to reduce their swelling characteristics $[10,19]$. Other stabilization method recommends the inclusion of coarse-grained soil like sand to improve the properties of clayey soil used as backfill material. In mixed soils study for example, as the proportion of sand in clayey soil is increased (up to $25-30 \%$, the engineering properties of the backfill material (dry density, shear strength and CBR values) were significatively performed [2, 20]. Tapas [20] worked on clayey soil from India as backfill material, and he stipulates that stabilization of compressible clays with locally available sand may be one of the cost effective and quick methods of improving the properties of such soils. In this regard, since the consistency index was substantially greater than 1, the studied soils, due to their fine nature and thus high compressibility, can be suitable as backfill material [2]. As a remedy to this limitation due to the swelling characteristics, a preliminary treatment with quick lime $(2-4 \%)$ or slaked lime (3-5\%) [1, 2] is suggested; thus, the mechanical characteristics of the studied clayey soils would be improved at a long term. On the contrary, that swelling behavior of Boulgou soils, thanks to their clayey nature 
Fig. 3 Position of Boulgou soils in some empirical diagrams: a Casagrande chart (USCS classification): Clay (C), Silt (M), Organic (O): Low plasticity (L), High plasticity $(\mathrm{H})$; b Triangular diagram of porosity and permeability (McManus [18]); c Diagram of Bain and Highley [21] showing samples acceptable (P1, P2) or optimum (P3, $\mathrm{P} 5)$ in extrusion brick-making
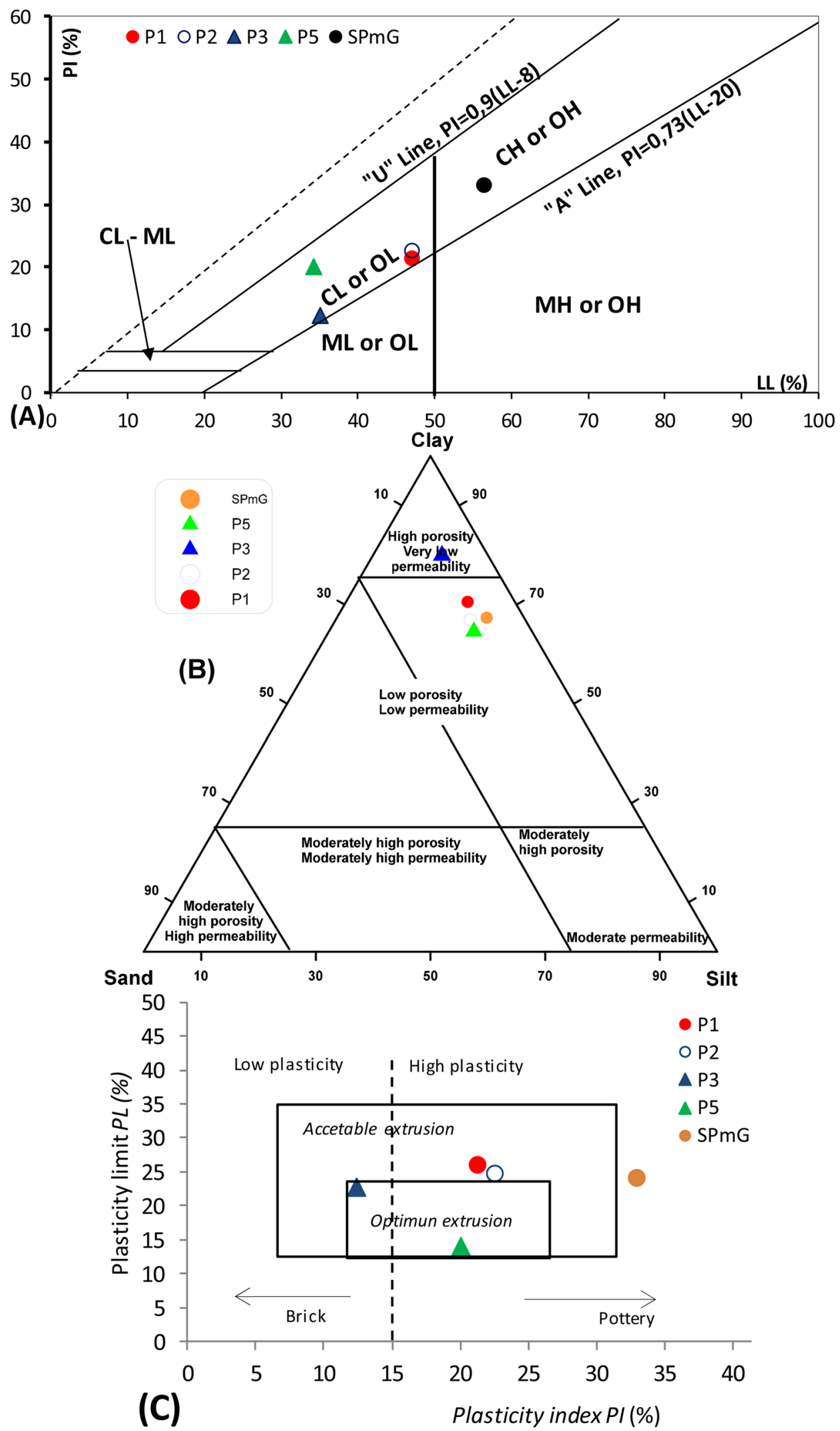
(fineness, low permeability, a degree of compactness $\sim 85 \%)$ may confirm the suitability of these soils in some engineering applications requiring barriers to water (core of an earthen dam for example). According to [11], sandy clayey soils can be considered semi-permeable materials, suitable for inclusion in the upstream shoulder of small earth dams. This kind of soils will allow a limited passage of water and, in a properly constructed embankment, will resist slumping when wet [11]. Based on the pottery activity observed in the locality, reinforced by the granulometric and plastic properties, a potential suitability for ceramics activities is suggested by those soils.

\subsection{Mineralogy and chemistry of the soils studied}

The mineralogy of clayey soils studied is shown in Fig. 4 and Table 4, which reveals a poly-mineralized material. The main minerals observed are: quartz, feldspars (albite, sanidine, anorthite and orthose), carbonates (ankerite, siderite, dolomite), amphibole, iron oxide (hematite) and clay minerals (smectite, kaolinite and illite). The existence of the smectite group suspected from field observation (swelling) and methylene blue is confirmed on the XRD obtained on bulk (Fig. 4a) and oriented aggregates (Fig. 4b).

Illite is recognized as a mineral which contributes to improve clay plasticity favoring the venue of vitreous phases during firing, thereby improving densification and strength of the ceramic material $[4,6,7]$. The existence of smectite in Boulgou soils may be linked to poor drainage, which is related to climatic conditions (less rainfall, low gradient slopes and high evaporation due to high temperature) in this northern part of the country; this fact considerably limits the external drainage. According to [24], the bisiallitization' weathering processes dominates in the Northern area of Cameroon and favors the presence of smectite. On the contrary, the monosiallitization processes which favors the presence of kaolinite generally dominates in areas with abundant rainfall. This fact can explain why Boulgou' soils present low proportions of kaolinite (6-12\%), less than those of materials (\% of kaolinite $>25 \%$ ) usually studied in the tropical humid climate zone [4-7]. XRD results can be also confirmed by FTIR spectra (Fig. 4c) were kaolinite, smectitic group and an oxyhydroxide-rich mineral can be observed. The characteristics peaks of kaolinite appear at $3695 \mathrm{~cm}^{-1}$ (U1), $3655 \mathrm{~cm}^{-1}$ (u3) and $3619 \mathrm{~cm}^{-1}$ (u4) and the lack of a welldefined peak of $U 2\left(3675-3668 \mathrm{~cm}^{-1}\right)$ may be related to the existence of disordered kaolinite on $(a, b)$ axes [25]. This evidenced also the lack of $\mathrm{Al}_{2} \mathrm{OH}$ bending at $938 \mathrm{~cm}^{-1}$, suggesting stacking faults along the " $c$ " axis, which confirmed the sedimentary origin of the clayey soils studied [25]. A board band near $3430 \mathrm{~cm}^{-1}$ has confirmed the existence of smectitic group minerals due to $\mathrm{H}-\mathrm{O}-\mathrm{H}$ vibrations of adsorbed water [26]. The water molecules are revealed by the wide band at $1626 \mathrm{~cm}^{-1}$.

The $\mathrm{SiO}_{2} / \mathrm{Al}_{2} \mathrm{O}_{3}$ ratio was $>3 \%$, indicative of an excess of $\mathrm{SiO}_{2}$, confirming the existence of 2:1 phyllosilicates of smectites type $[5,24]$. The existence of hematite $(<2 \%)$ is tributary to the significant iron oxide contents $\mathrm{Fe}_{2} \mathrm{O}_{3}$ (6-8\%) and may be responsible for the reddish color of specimen after firing. Carbonates ( 4 to $6 \%$ on average) exist in the form of calcite, ankerite or dolomite. These minerals are indicators of a calm sedimentary environment probably from a marine domain [27], and their occurrence is related to the high concentration of ions like $\left(\mathrm{Ca}^{2+}, \mathrm{CO}_{3}{ }^{-}, \mathrm{Mg}^{2+}, \mathrm{Fe}^{2+}\right)$. After precipitation of calcite, dolomite $\left(\mathrm{MgCa}\left(\mathrm{CO}_{3}\right)_{2}\right)$ and ankerite $\left(\mathrm{FeMgCa}\left(\mathrm{CO}_{3}\right)_{2}\right)$ are formed metasomatically. $\mathrm{CaO}(2-3.7 \%), \mathrm{MgO}(1-3 \%)$ and $\mathrm{Fe}_{2} \mathrm{O}_{3}(6-8 \%)$ observed in XRF results further confirm the existence of these minerals. While observing the current field environment, the abundance of sedimentary rocks of the Tinguelin massif suggests that the site was a favorable environment for sedimentation several millions of years ago. The deposition milieu of the Tinguelin mound would correspond to a meandriform fluvial domain where detrital inputs are conveyed by medium to high energy fluxes (sandstones with medium-sized micro-organisms [12]). According to $[4,28]$, the presence of carbonates in soils does not make them unsuitable for the manufacture of structural ceramics (roofing tiles) and fine ceramics (floor tiles and faience). In the studied clayey soils, their content was relatively low $(<6 \%)$, but they were present in all samples analyzed including the sandy sample (P4). The main peaks of feldspar (albite, anorthite, orthose) were very common in the samples' diffractograms, as evidenced by their contents in alkali $\left(\mathrm{Na}_{2} \mathrm{O}+\mathrm{K}_{2} \mathrm{O}, \sim 5\right.$ to $\left.6 \%\right)$ and earthalkali (CaO $+\mathrm{MgO}, \sim 4$ to $5 \%$ ) elements found in XRF results. These minerals were very good fluxing agents in ceramics manufacturing. Their presence is known to reduce melt temperature and contribute to rapid vitrification behavior as from $900{ }^{\circ} \mathrm{C}$. Therefore, the porosity characteristics of fired bodies are strongly reduced by melting liquid at elevated temperatures. Mullite formation is promoted by kaolinite while the apparition of glassy phase assuring good densification for the specimens fired $[4,6]$ is favored by illite and smectite. However, the presence of smectite may display high potential of cracking during drying or firing, but excessive shrinkage is not expected because the studied clays have $\mathrm{PI}<35$ according to [23]. The presence of those fluxing agents may be related to the lithological formation and climate conditions in the studied area. This can be confirmed because Oluwole et al. [29], working on clayey materials from basaltic rock in Nigeria for burnt bricks showed that content of fluxing oxides is low $(<2 \%)$ and smectite is absent in their raw materials, which consequently affected the technological properties of the 


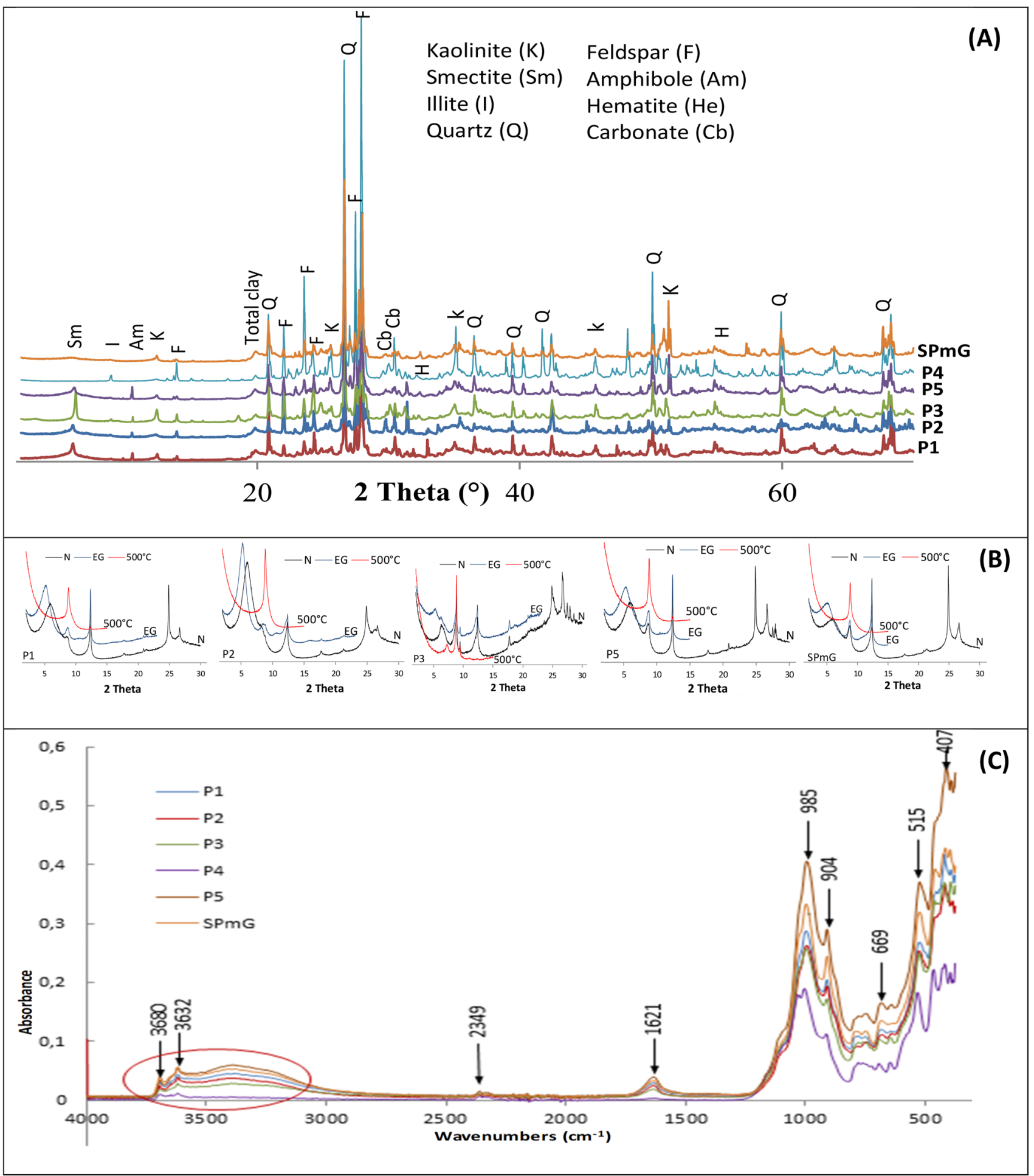

Fig. 4 XRD patterns of samples a Bulk XRD pattern; K: kaolinite, Q: Quartz; Felds: Feldspar. b Clay<2 $\mu$ m pattern; N: air dried condition; EG glycolated condition with ethylene glycol for $22 \mathrm{~h}$; H: heated at condition $\left(500^{\circ} \mathrm{C}\right.$ for $\left.4 \mathrm{~h}\right)$. c FTIR curves of clays studied

burnt products. In the studied clays, the quartz content (15-19\%) refers to the silica $\left(\mathrm{SiO}_{2}\right)$ content $(50-60 \%)$. This equally influences the samples' plasticity as quartz acts as a filler material. Its presence could also decrease the firing shrinkage and this fact was attributed by El Ouahabi et al. [30] to the transition of alpha to beta quartz at $573^{\circ} \mathrm{C}$ accompanied by an increasing of volume. Guzlena et al. [31] specify that when the reversible reaction is backed 
Table 4 Mineral and chemical composition of Boulgou clayey soils

\begin{tabular}{|c|c|c|c|c|c|}
\hline & P1 & P2 & P3 & P5 & SPmG \\
\hline \multicolumn{6}{|l|}{ Chemical composition (wt\%) } \\
\hline $\mathrm{SiO}_{2}$ & 58.56 & 51.76 & 58.90 & 57.29 & 58.8 \\
\hline $\mathrm{Al}_{2} \mathrm{O}_{3}$ & 16.02 & 18.50 & 15.19 & 16.73 & 1.56 \\
\hline $\mathrm{Fe}_{2} \mathrm{O}_{3}$ & 6.13 & 8.54 & 6.83 & 5.66 & 6.50 \\
\hline $\mathrm{K}_{2} \mathrm{O}$ & 2.64 & 2.24 & 3.26 & 2.86 & 3.0 \\
\hline $\mathrm{MgO}$ & 0.98 & 1.45 & 2.89 & 1.24 & 1.94 \\
\hline $\mathrm{TiO}_{2}$ & 1.11 & 1.68 & 1.39 & 1.31 & 1.30 \\
\hline $\mathrm{P}_{2} \mathrm{O}_{5}$ & 0.24 & 0.42 & 0.41 & 0.19 & 0.32 \\
\hline $\mathrm{CaO}$ & 2.78 & 3.75 & 1.56 & 2.91 & 2.18 \\
\hline $\mathrm{Na}_{2} \mathrm{O}$ & 2.27 & 2.57 & 2.59 & 2.18 & 2.44 \\
\hline $\mathrm{MnO}$ & 0.08 & 0.09 & 0.13 & 0.08 & 0.12 \\
\hline Loss of ignition $\left(1000^{\circ} \mathrm{C}\right)$ & 6.97 & 7.44 & 6.42 & 7.94 & 6.72 \\
\hline Total & 97.78 & 98.45 & 99.56 & 98.39 & 98.88 \\
\hline $\mathrm{SiO}_{2} / \mathrm{Al}_{2} \mathrm{O}_{3}$ & 3.65 & 2.80 & 3.88 & 3.42 & 3.78 \\
\hline $\begin{array}{c}\mathrm{TiO}_{2}+\mathrm{Fe}_{2} \mathrm{O}_{3}+\mathrm{MgO}+\mathrm{Ca} \\
\mathrm{O}+\mathrm{Na}_{2} \mathrm{O}+\mathrm{K}_{2} \mathrm{O}\end{array}$ & 15.91 & 20.24 & 18.50 & 16.15 & 17.36 \\
\hline \multicolumn{6}{|c|}{ Mineralogical composition (\%) } \\
\hline Smectite & 4 & 5 & 6 & 4 & 3 \\
\hline Illite & 8 & 8 & 8 & 10 & 8 \\
\hline Kaolinite & 12 & 6 & 5 & 6 & 12 \\
\hline Quartz & 18 & 11 & 21 & 16 & 18 \\
\hline Feldspar & 48 & 63 & 52 & 56 & 53 \\
\hline Carbonate & 6 & 4 & 4 & 4 & 4 \\
\hline Amphibole & 2 & 1 & 2 & 3 & - \\
\hline Hematite & 2 & 2 & 2 & 1 & 2 \\
\hline
\end{tabular}

to alpha quartz during inadequately executed cooling, an opened space is left on the sintered clay due to the decrease in quartz volume ( $0.8 \%)$ [31]. Reasonably high quartz content probably contributes to the improvement of geotechnical characteristics of soil (such as dry density, compaction, stiffness and shear resistance) [2] and also reduces shrinkage behavior for sintered ceramic products $[6,23,24,30,31]$.

\subsection{Firing properties}

A slightly metallic sound at $850^{\circ} \mathrm{C}$ and a metallic sound beyond $900{ }^{\circ} \mathrm{C}$ (Table 5) are shown by the firing properties of bricks specimens. All specimens from 850 to $1200{ }^{\circ} \mathrm{C}$ presenting an average or a good cohesion and no defect (as cracks) were observed. Below $1050{ }^{\circ} \mathrm{C}$, the color is reddish to brown red or gray red at $1200^{\circ} \mathrm{C}$. Specimen P3 at $1200^{\circ} \mathrm{C}$ shows a vitrified product (Fig. 5), probably due to the formation of a liquid phase. The metallic sound probably reflects the good sintering of the fired specimens [7]. According to [32], the color of fired clay depends upon its chemical composition, the firing temperatures and the method of firing. The presence of iron oxide $\left(\mathrm{Fe}_{2} \mathrm{O}_{3}\right)$ exhibits a shade of red when exposed to an oxidizing fire because of the formation of ferrous oxide ( $\mathrm{FeO}$ ). During firing at a reduced atmosphere, the same clay will assume a dark (or black) color. Also, the presence of titane oxide $\left(\mathrm{TiO}_{2}\right)$ may favor dark color [7, 30]. Shrinkage, bulk density and flexural strength increased with temperature while water absorption coefficient decreased (Fig. 6). The linear shrinkage values were less than $2 \%\left(<950^{\circ} \mathrm{C}\right), 4 \%\left(<1100^{\circ} \mathrm{C}\right)$ and $10 \%\left(<1200^{\circ} \mathrm{C}\right)$. The small value of shrinkage may be due to the breakdown of the clay structure at this temperature, the beginning of the vitreous phases and the occurring of the thermal decomposition of carbonates [30]. The values of shrinkage recommended for good quality bricks must be below 4\% [30,32], and for clayey soils studied, the values were within the recommended limits at temperature $<1100^{\circ} \mathrm{C}$. Above this temperature, firing shrinkage values were beyond the industrial limits for brick production [30]. The bulk density values increased from 1.7 to $2.3 \mathrm{~g} / \mathrm{cm}^{3}$ (at $1200^{\circ} \mathrm{C}$ ), confirming the mineralogical transformations that occurred such as mullite formation originating from the melting of feldspar. However, and according to $[4,30]$ the presence of smectite, mineralization may limit the extent of densification at temperature less than $1000^{\circ} \mathrm{C}$, due to the fact that its dehydroxylation is followed by expansion of the crystal network. Above $1000^{\circ} \mathrm{C}$, a liquid phase produced by flux agents such as potassium, increase the density. Thus, the melting liquid facilitates rearrangement reactions during sintering which favors shrinking and densification behavior of the fired products $[7,28$, 30-33]. The water absorption is related to microstructure and determines the open porosity level of the sintering product. Its values ranged from 15 to $19.2 \%\left(<1050{ }^{\circ} \mathrm{C}\right)$, $13 \%$ to $17 \%\left(<1100^{\circ} \mathrm{C}\right)$ and decrease again $(1.3-4.8 \%)$ at $1200^{\circ} \mathrm{C}$. At high temperature, the abundance of liquid phase helped to reduce the open porosity which consequently decreased the water absorption. The values of water absorption were less than $20 \%$, which represents the recommended water absorption value of fired bricks in tropical countries [5, 33]. The values $<4 \%$ suggest suitability for gres ceramics (EN 100,1982) which include low porosity products such as sanitary ware and tile. The bending strength of the studied specimens increased from $900{ }^{\circ} \mathrm{C}(<1.5 \mathrm{MPa})$ to $1200{ }^{\circ} \mathrm{C}(<17 \mathrm{MPa})$. The low values $(<1.5 \mathrm{MPa})$ can be attributed to the poor fusibility at this temperature level which do not favor melting liquid apparition and consequently, no strong densification of the fired products. Feldspar was melted at temperature higher than $1150{ }^{\circ} \mathrm{C}$, and the melting liquid is responsible of the consolidation and vitrification. At high temperature, the high values of bending strength could be related to mullite formation. The minimum required 
Table 5 Physical properties of fired specimens

\begin{tabular}{|c|c|c|c|c|c|c|c|c|}
\hline Samples & $T\left({ }^{\circ} \mathrm{C}\right)$ & Color & $\begin{array}{l}\text { Observation of } \\
\text { the cohesion* }\end{array}$ & Sonority & $\begin{array}{l}\text { Linear } \\
\text { shrinkage } \\
\text { (\%) }\end{array}$ & $\begin{array}{l}\text { Water } \\
\text { absorption } \\
\text { (\%) }\end{array}$ & $\begin{array}{l}\text { Bulk density } \\
\left(\mathrm{g} / \mathrm{cm}^{3}\right)\end{array}$ & $\begin{array}{l}\text { Flexural } \\
\text { strength } \\
(\mathrm{MPa})\end{array}$ \\
\hline \multirow[t]{7}{*}{ P1 } & 850 & 5 YR 5/8 Reddish & & Slightly metallic & 0,3 & 17,9 & 1,7 & 0,5 \\
\hline & 900 & & Average & Metallic & 0,4 & 18 & 1,7 & 0,8 \\
\hline & 950 & & & & 0,3 & 17,3 & 1,7 & 3,5 \\
\hline & 1000 & & Good & & 0,6 & 16 & 1,9 & 5,3 \\
\hline & 1050 & 5 YR 5/4 Brown red & & & 0,7 & 15,9 & 1,9 & 8,2 \\
\hline & 1100 & & Good & & 2,2 & 14,4 & 2 & 10,6 \\
\hline & 1200 & 5YR5/2Gray red & Good & & 9,4 & 2 & 2,32 & 16,6 \\
\hline \multirow[t]{7}{*}{ P2 } & 850 & 5 YR 5/8 Reddish & & Slightly metallic & 0,3 & 17 & 1,9 & 0,4 \\
\hline & 900 & & Good & Metallic & 0,7 & 16,8 & 1,8 & 0,5 \\
\hline & 950 & & & & 0,7 & 16,8 & 1,8 & 2,6 \\
\hline & 1000 & & Good & & 1 & 16 & 1,9 & 4,1 \\
\hline & 1050 & 5 YR 5/4 Brown red & & & 1,3 & 15,6 & 1,9 & 5,8 \\
\hline & 1100 & & Good & & 2,5 & 13,3 & 2 & 8,4 \\
\hline & 1200 & 5YR5/2Gray red & Good & & 8,3 & 1,85 & 2,36 & 14,8 \\
\hline \multirow[t]{7}{*}{ P3 } & 850 & 5 YR 5/8 Reddish & & Slightly metallic & 1,5 & 16,7 & 1,8 & 0,4 \\
\hline & 900 & & Weak & Metallic & 1,5 & 17,1 & 1,8 & 0,4 \\
\hline & 950 & & & & 1,5 & 16,9 & 1,8 & 2,2 \\
\hline & 1000 & & Weak & & 2,3 & 17,9 & 1,8 & 3,2 \\
\hline & 1050 & 5 YR 5/4 Brown red & & & 2,4 & 15,5 & 1,9 & 4,2 \\
\hline & 1100 & & Average & & 3,7 & 12,8 & 2 & 7 \\
\hline & 1200 & 5YR5/2Gray red & Good & Metallic \& vitrified & 6,3 & 1,3 & 2,31 & 17,4 \\
\hline \multirow[t]{7}{*}{ P5 } & 850 & 5 YR 5/8 Reddish & & Slightly metallic & 0,3 & 19,6 & 1,7 & 0,4 \\
\hline & 900 & & Average & Metallic & 0,6 & 19,6 & 1,7 & 0,6 \\
\hline & 950 & & & & 0,6 & 19,7 & 1,7 & 2,5 \\
\hline & 1000 & & Good & & 0,7 & 19 & 1,8 & 3,9 \\
\hline & 1050 & 5 YR 5/4 Brown red & & & 1,1 & 18,7 & 1,8 & 4,9 \\
\hline & 1100 & & Good & & 1,6 & 16,9 & 1,9 & 7,8 \\
\hline & 1200 & 5YR5/2Gray red & Good & & 7,8 & 3,8 & 2,3 & 15,1 \\
\hline \multirow[t]{7}{*}{ SPmG } & 850 & 5 YR 5/8 Reddish & Average & Slightly metallic & 0,4 & 17,4 & 1,7 & 0,4 \\
\hline & 900 & & & Metallic & 0,7 & 18,9 & 1,7 & 0,6 \\
\hline & 950 & & & & 0,7 & 19 & 1,7 & 3,1 \\
\hline & 1000 & & Good & & 1,1 & 17,4 & 1,8 & 4,2 \\
\hline & 1050 & 5 YR 5/4 Brown red & & & 1,3 & 15,7 & 1,8 & 5,3 \\
\hline & 1100 & & Good & & 2,9 & 14,7 & 1,9 & 8,1 \\
\hline & 1200 & 5YR5/2Gray red & Good & & 5,5 & 1,4 & 2,2 & 16,2 \\
\hline
\end{tabular}

*The assessment of the cohesion of the fired specimens was made up by visual observation of the fired products

value for normal fired brick is $7 \mathrm{MPa}$ [34], which helped us to conclude that clayey soils from Boulgou could be used for fired bricks as from $1050^{\circ} \mathrm{C}$.

\section{Conclusion}

This study focused on some geotechnical and mineralogical characteristics of clayey soils in order to evaluate their potentialities in engineering applications such as backfill material and potential fusible raw material. Based on the results obtained from the field and laboratory tests, the following conclusions were reached:

1. The studied clayey soils in Boulgou area, North region of Cameroon, are sediments deposited in more or less distinct layers with overall thickness varying between 2 and $3.5 \mathrm{~m}$. Six samples (P1 to P5 and SPmG) were collected in wells dug. They were clay sand (SC) for P1, P2, P5 and SPmG, silty clay (SC) for P3 and poorly graded 

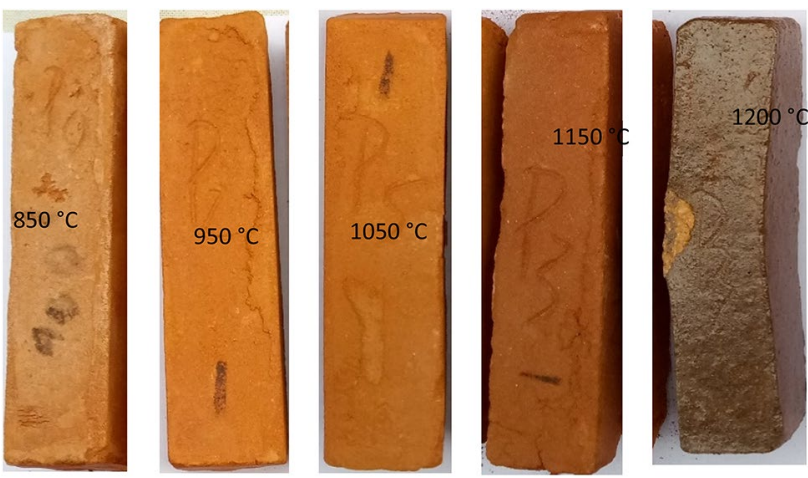

Fig. 5 Pictures of fired specimens

sand (SP) for P4 according the USCS classification, with low plasticity $(\mathrm{CL})$ for $\mathrm{P} 1, \mathrm{P} 2, \mathrm{P} 3$ and $\mathrm{P} 5$ and high plasticity $(\mathrm{CH})$ for SPmG. They were low-permeability and high/low-porosity materials in McManus diagram's, thus easily extrudable in ceramic process; “ $\mathrm{CH}^{\prime}$ may be considered as marginal backfill material while " $\mathrm{CL}^{\prime}$ were relatively impervious and could be fairly easily compacted;

2. The swelling behavior of Boulgou soils, their clayey nature (fineness $\sim 27$ to $53 \%$, methylene blue values
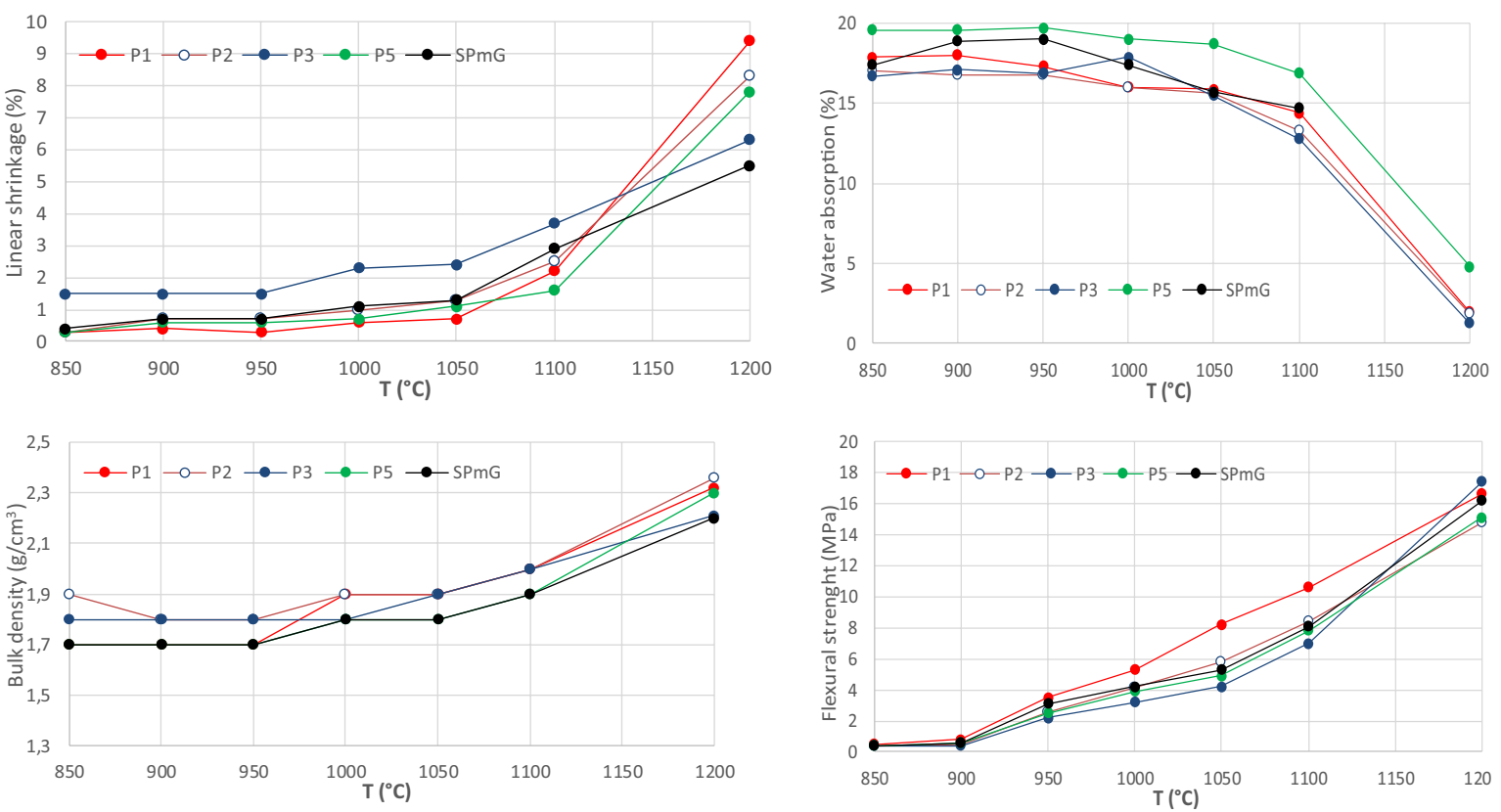

Fig. 6 Evolution of firing properties

$\sim 3$ to 5 , low permeability and high compressibility, a degree of compactness $\sim 85 \%$ ) may confirm the suitability of theses soil in some engineering applications. Those properties make them useful in civil engineering projects with preliminary treatment in some cases. For example, quick lime $\sim 2$ to $4 \%$ or slaked lime $\sim 3$ to $5 \%$ could reduce their swelling characteristics or sand additive up to $25-30 \%$ could perform their engineering properties like dry density and shear strength;

3. Combined with the mineralogy and chemistry characteristics observed (smectite 3-6\%, illite: 8-10\%, feldspar $48-63 \%$ and alkali $\mathrm{Na}_{2} \mathrm{O}+\mathrm{K}_{2} \mathrm{O}, \sim 5$ to $6 \%$ and earth-alkali $\mathrm{CaO}+\mathrm{MgO}, \sim 4$ to $5 \%$ ), the studied clayey soils are lusting for ceramists as evidenced by the pottery activities in the locality. These minerals were very good fluxing agents in ceramics manufacturing;

4. Their firing characteristics at temperatures ranging from 850 to $1200{ }^{\circ} \mathrm{C}$, as for building materials, presented them as suitable for brick-making with the best properties as from $1050^{\circ} \mathrm{C}$. At high temperature $\left(1200^{\circ} \mathrm{C}\right)$, the abundance of liquid phase helped to reduce the open porosity. The water absorption values $<4 \%$ suggested suitability for gres ceramics which included low porosity products such as sanitary ware and tile. 
Funding This project was funded personally by the authors.

Availability of data and material The data used in this current study are available from the corresponding author on upon request.

\section{Declarations}

Conflict of interest The authors declare that there is no conflict of interest.

Open Access This article is licensed under a Creative Commons Attribution 4.0 International License, which permits use, sharing, adaptation, distribution and reproduction in any medium or format, as long as you give appropriate credit to the original author(s) and the source, provide a link to the Creative Commons licence, and indicate if changes were made. The images or other third party material in this article are included in the article's Creative Commons licence, unless indicated otherwise in a credit line to the material. If material is not included in the article's Creative Commons licence and your intended use is not permitted by statutory regulation or exceeds the permitted use, you will need to obtain permission directly from the copyright holder. To view a copy of this licence, visit http://creativecommons. org/licenses/by/4.0/.

\section{References}

1. Holtz RD, Kovacs WD (1981) An introduction to geotechnical engineering. Prentice Hall Inc, New Jersey

2. Gökalp Z (2009) Engineering characteristics of sand-clay mixtures used for clay cores of earth-fill dams. Clay Min 44(3):319-326

3. Abdullah MMAB, Ming LY et al (2018) Clay-based materials in geopolymer technology. Cement Based Mater. https://doi.org/ 10.5772/intechopen.74438

4. Nzeukou NA, Traina K, Medjo ER et al (2014) Mineralogical and physical changes during sintering of plastic red clays from Sanaga Swampy Valley, Cameroon. Interceram 63:4-5

5. Tsozué D, Nzeukou Nzeugang A, Mache JR et al (2017) Mineralogical, physico-chemical and technological characterization of clays from Maroua (Far-North, Cameroon) for use in ceramic bricks production. J Build Eng 11:17-24

6. Kamseu E, Leonelli C, Boccaccini DN et al (2007) Characterization of porcelain compositions using two china clays. Ceram Int 33:851-857

7. Nzeukou Nzeugang A, Medjo ER, Fagel N et al (2013) Characterization of clay deposits of Nanga-Eboko (central Cameroon): suitability for the production of building materials. Clay Miner 48:655-662

8. Ekrem Kalkan AEM, Salih B (2008) Geotechnical evaluation of Turkish clay deposits: a case study in Northern Turkey. Environ Geol 5(5):937-950

9. Shi B, Jiang H, Liu Z (2002) Engineering geological characteristics of expansive soils in China. Eng Geol 67:63-71

10. Guyer JP (2017) An introduction to fondations structures, 2nd edn. J. Paul Guyer, P.E., R.A. Ed. The Clubhouse Press El Macero, California

11. Tim S (2010) Manual on small earth dams. A guide to siting, design and construction. FAO irrigation and drainage paper 64 . FAO of the United Nations, Rome

12. Bessong $M$, Abderrazak EA, Hell JV et al (2011) Diagenesis in cretaceous formations of Benue trough in the Northern part of Cameroon: Garoua sandstones. World J Eng Pure Appl Sci 1(3):58
13. Robitaille V, Tremblay D (1997) Mécanique des sols. Théorie et pratique, Québec

14. Moore Duane M, Reynolds Robert Jr. C (1989) X-ray diffraction and the identification and analysis of clay minerals. Oxford University Press, Oxford

15. Fagel N, Boski T, Likhoshway L et al (2003) Late quaternary clay mineral record in Central Lake Baikal (Academician Ridge, Siberia). Paleogeo Paleoclim Paleoeco 193(1):159-179

16. Saleiro GT, Holanda JNF (2012) Processing of red ceramic using a fast-fring cycle. Cerâmica 58:393-399

17. Antoine $P$, Fabre $D$ (1980) Géologie appliquée au génie civil. Paris

18. McManus J (1988) Grain size distribution and interpretation. In: Tucker ME (ed) Techniques in sedimentology. Blackwell Scientific Publications, Oxford, pp 63-85

19. Suryakanta (2016) Types of backfill materials used in construction. https://civilblog.org/2016/03/04/6-types-of-backfill-mater ials-used-in-construction. Accessed 17 Feb 2021

20. Dasgupta T (2014) Compressible clay soil as backfill material: problems and remedial measures. Int J Sci Eng Technol 7(3):887-889

21. Bain JA, Highley DE (1979) Regional appraisal of clay resources. A challenge to the clay mineralogist. Dev Sedimentol 27:437-446

22. Vieira CMF, Sanchez R, Monteiro SN (2008) Characteristics of clays and properties of building ceramics in the state of Rio de Janeiro, Brazil. Constr Build Mater 22:781-787

23. Daoudi L, Elboudour EH, Saadi L et al (2014) Characteristics and ceramic properties of clayey materials from Amezmiz region (Western High Atlas, Morocco). Appl Clay Sci 102:139-147

24. Nguetnkam JP, Villiéras F, Kamga R et al (2014) Mineralogy and geochemical behaviour during weathering of greenstone belt under tropical dry conditions in the extreme North Cameroon (Central Africa). Chem Erde 74:185-193

25. Cases JM, Lietard O et al (1982) Etude des propriétés cristallochimiques, morphologiques, superficielles de kaolinites désordonnées. Bull Min 5(105):439-456

26. Madejova J (2003) FTIR techniques in clay mineral studies: review. Vib Spectrosc 31:1-10

27. Boulvain $F$ (2019) Diagenèse carbonatée. Ulg. Pétrologie sédimentaire. http://www.geolsed.ulg.ac.be/sedim/diagenese.htm. Accessed 15 Feb 2020

28. Carretero MI, Dondi M et al (2002) The influence of shaping and firing technology on ceramic properties of calcareous and noncalcareous illitic-chloritic clays. Appl Clay Sci 20:301-306

29. Oluwole GA, Amponsah-Dacosta F, Sphiwe EM (2020) Geotechnical evaluation of clayey materials for quality burnt bricks. Heliyon 6:e05626

30. El Ouahabi M, Daoudi L, Fagel N (2016) Technological behaviour of Cretaceous and Pliocene clays of northern Morocco used in fired brick manufacturing. J Mater Environ Sci 9(4):1140-1151

31. Guzlēna S, Šakale G, Čertoks S (2017) Clayey material analysis for assessment to be used in ceramic building materials. Procedia Eng 172:333-337

32. BIA (2006) Technical notes on brick construction: manufacturing of brick. Brick Industry Association, Virginia

33. Melo CU, Kamseu E, Djangang C (2003) Effect of fluxes on the fired properties between $950-1050^{\circ} \mathrm{C}$ of some Cameroonian clays. Tiles Bricks Int 19(6):57-69

34. Sigg J (1991) Les produits de terre cuites. SEPTIMA, Paris

Publisher's Note Springer Nature remains neutral with regard to jurisdictional claims in published maps and institutional affiliations. 